\title{
Faunistické společenstvo kroměřižského souvrství na lokalitě Litenčice (karpatská předhlubeň, střední Morava)
}

\author{
Faunistic assemblage of the Kroměříž Formation in Litenčice locality (Carpathian
} Foredeep, Central Moravia)

\section{Růžena Gregorová1 $\rightrightarrows$, Pavla Tomanová Petrová2, Helena Gilíková2, Slavomír Nehyba ${ }^{3}$, Rostislav Brzobohatý3, Šárka Hladilová4, Matúš Hyžný5 ${ }^{5}$ Kamil Zágoršek6, Lucie Kleprlíková ${ }^{3}$}

\author{
${ }^{1}$ Moravské zemské muzeum, Zelný trh 6, 65937 Brno, Česká republika \\ ${ }^{2}$ Česká geologická služba, Leitnerova 22, 65869 Brno, Česká republika \\ ${ }^{3}$ Ústav geologických věd, PřF Masarykovy Univerzity, Kotlářská 2, 61137 Brno, Česká republika \\ ${ }^{4}$ Katedra biologie, PdF Univerzity Palackého, Purkrabská 2, 77140 Olomouc, Česká republika \\ ${ }^{5}$ Katedra geologie a paleontologie Univerzity Komenského v Bratislavě, Mlynská dolina, Ilkovičova 6, \\ 84215 Bratislava, Slovenská republika \\ ${ }^{6}$ Katedra geografie, fakulta prírodnè-humanitní a pedagogická, Technická Univerzita v Liberci, Studentská 1402/2, \\ 46117 Liberec 1, Česká republika
}

Key words:

Carpathian Foredeep, Kroměřiž Formation, Karpatian, Paleontology, Sedimentology, Paleoecology

$\Xi$ rgregorova@mzm.cz

Editor:

David Buriánek

\begin{abstract}
The fossil assemblages of the foraminifers, bryozoans, molluscs, corals, decapods, sharks and teleosteans were analysed from the Litencice sand pit in the middle part of the Carpathian Foredeep. The section can be assigned to the Karpatian Stage of the Central Paratethys regional stratigraphy (uppermost Lower Miocene) on the basis of species Uvigerina graciliformis Papp et Turn., Lampanyctus carpaticus (Brz.) and Agapilia pachii (Hoern.). Rich and diversified assemblages indicate mainly shallow water marine environment. Foraminifers and molluscs indicate salinity perturbations. Bryozoans and also molluscs document environment with relatively high dynamics and depth of water about $100 \mathrm{~m}$. Foraminifers, fishes and sharks represent deeper water taxa and indicate a possible reworking of shallow-water elements. The studied sands and gravels of the Holešov Member of the Kromerriž Formation are interpreted as sediments of gravitational currents, more precisely dense turbidity currents (high-density turbidity currents) in the sense of Lowe (1982). The deposition environment can probably be placed on the submarine slope of the coarse-grained delta of the Gilbert type (so-called foresets). This study provided evidence of a number of fossil groups that occur at the site.
\end{abstract}

\section{Doporučená citace článku:} Gregorová, R., Tomanová Petrová, P. Gilíková, H., Nehyba, S., Brzobohatý, R., Hladilová, Š., Hyžný, M., Zágoršek, K., Kleprlíková, L. (2020). Faunistické společenstvo kroměřižského souvrství na lokalitě Litenčice (karpatská předhlubeň, střední Morava. Geologické výzkumy na Moravě a ve Slezsku, 27, 1-2, 45-53.

DOI: https://doi.org/10.5817/ GVMS2020-13582

\section{Úvod}

Předmětem výzkumu je „Gregorova pískovna“, která se nachází v z. části katastru obce Litenčice $\left(\mathrm{N} 49^{\circ} 12,21882^{`} \mathrm{E} 17^{\circ} 11,36262^{\prime}\right)$ s. od silnice vedoucí do Nítkovic mezi polními tratěmi Žleby a Jaboří (obr. 1). Z regionálně geologického hlediska lokalita náleží karpatské předhlubni, která zde bezprostředně hraničí s flyšovým pásmem Západních Karpat (ždánická jednotka). V pískovně jsou odkryty spodnomiocenní sedimenty patřící kroměřižskému souvrství, které je zde zastoupeno holešovskými vrstvami. Představují nejmladší fázi sedimentace karpatu s klastickým materiálem derivovaným převážně z čel zvedajících se flyšových př́ikrovů (Francírek, Nehyba 2017). Další nejbližší výchoz holešovských vrstev se nachází v katastru obce Nítkovice v blízkosti osady Kozojedsko (N $\left.49^{\circ} 13^{`} 11,8^{\prime \prime} \mathrm{E} 17^{\circ} 09^{`} 20,8^{\prime \prime}\right)$, nebyl však předmětem studia.

Gregorova pískovna má tvar podkovy o průměru asi $20 \mathrm{~m}$ a výšce stěn maximálně do $6 \mathrm{~m}$. Je př́stupná pouze ze s. strany. Její současný stav je výsledkem dřívější těžby, která pochází dle pamětníků již z období 1. poloviny 20. století, kdy sloužila jako místní zdroj písku. Těžba byla ukončena v 90 . letech 20. století. V roce 1986 proběhl v pískovně průzkum společnosti Geologický průzkum n. p. Ostrava na zjištění zásob pro použití písku při stavbě silnice Brankovice - Uherský Brod (Košinarová et al. 1986). 


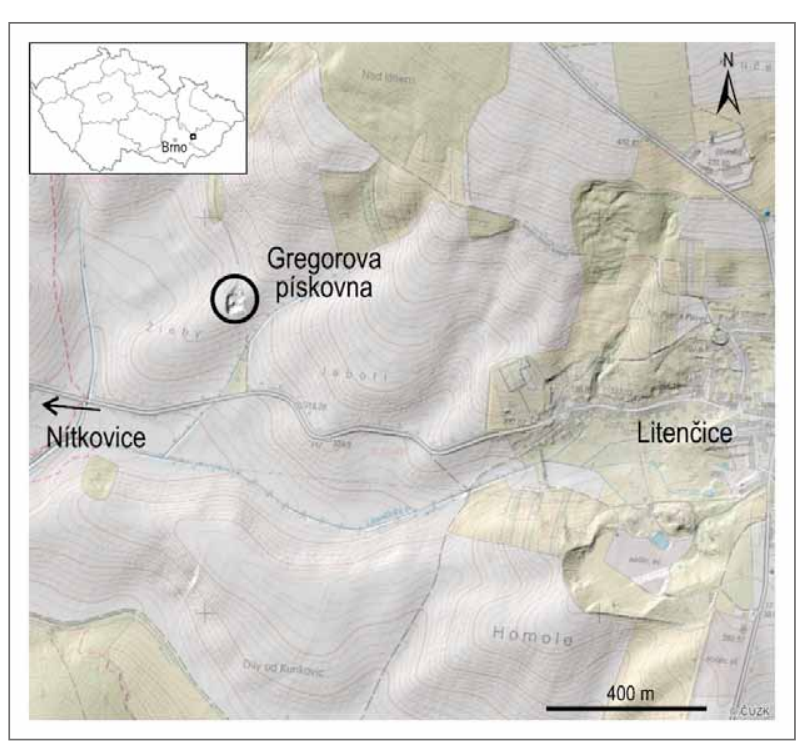

Obr. 1: Poloha "Gregorovy pískovny“"v katastru Litenčic. Fig. 1: Position of "Gregor sandpit" near Litenčice.

Nejstarší zmínka o zkamenělinách z Litenčic pochází z poloviny 19. století. Člen spolku Werner Verein dr. Josef Melion (1853) popsal od Litenčic poměrně bohatou faunu měkkýšů: Ancillaria inflata Lam., Ancillaria glandiformis Lam., Cancellaria acutangularis Fauj., Cerithium lignitarum Eichw., Turritella vindobonensis Partsch, Turritella acutangularis Brocchi, Tritonium corrugatum Lam., Solarium variegatum Brocchi, Natica millepunctata Lam., Pectunculus pulvinatus Brongn., Dentalium elephantinum Lam., Turbinolia duodecimcostata Goldf. a kromě nich ještě zlomky schránek rodů Terebra, Pleurotoma, Fusus, Ostrea a Venus. Není však jasné, odkud přesně nálezy pocházely. Podle pamětníků v okolí studované pískovny bylo $\mathrm{v}$ minulosti otevřeno více malých pískoven s lokální těžbou. Jelikož Melionův materiál nelze dohledat, nevíme, zda determinace odpovídá dnešní systematice, nebot' většina $\mathrm{z}$ uvedených taxonů

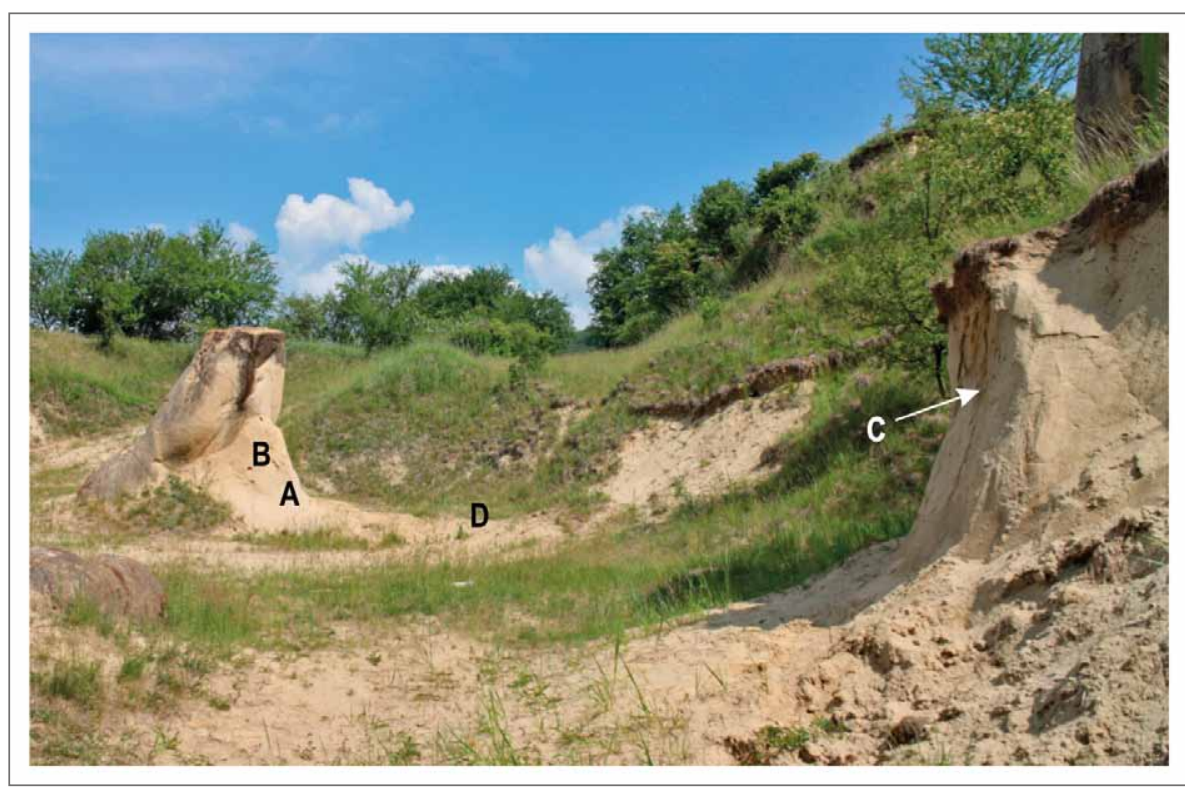

Obr. 2: Celkový pohled na pískovnu s odběrovými místy vzorků (A, B, C, D).

Fig. 2: General view of the sandpit with sampling points (sample $A, B, C, D$ ). není validní. Kromě této historické zmínky neexistuje žádná odborná paleontologická publikace o této lokalitě. Lokalita je evidována v Databázi významných lokalit ČGS (http://lokality.geology.cz/4128). Důvodem pro její zařazení je ojedinělý odkryv v píscích kroměřǐžského souvrství karpatu, v neposlední řadě také hnízdění vlhy pestré.

Předložená práce se zabývá sedimentologickým zhodnocením lokality a komplexním studiem paleontologického materiálu v bývalé pískovně.

\section{Materiál a metodika}

Sedimentologická analýza byla uskutečněna ve stávajících stěnách těžebny. Litofaciální analýza a následná interpretace depozičního prostředí byla provedena dle zásad uvedených v pracích Walkera (ed.) (1984), Tuckera (1988), Walkera a Jamese (1992), Nemece (2005) a Posamentiera a Walkera (2006). Ze zpevněné pískovcové vrstvy byl odebrán vzorek na výbrus za účelem petrografického zhodnocení sedimentu. Výbrus byl studován na mikroskopu Nicon Eclipse ME600.

Paleontologický materiál z povrchových sběrů z 80. let 20. století obsahuje měkkýší a korálovou faunu. $\mathrm{V}$ roce 2019 byl doplněn materiálem získaným plavením asi $15 \mathrm{~kg}$ písku, který byl odebrán při bázi pískovcových konkrecí (obr. 2, vzorek D). Vzorek obsahoval foraminifery, mechovky, měkkýše, korálnatce, desetinožce, žraloky a kostnaté ryby. Nově byly rovněž v roce 2019 odebrány 3 vzorky na mikropaleontologické studium z písku pod pískovcovým tělesem tvaru menhiru ve středu pískovny (viz obr. 2), z jílového závalku v písku tamtéž a $\mathrm{z}$ jílové polohy v píscích ve v. stěně pískovny (obr. 3). Materiál je uložen ve sbírkách Moravského zemského muzea a v České geologické službě v Brně.

Pro studium foraminifer byly vzorky namočeny do roztoku jedlé sody a poté plaveny na sítě o velikosti oka $0,063 \mathrm{~mm}$. Přeplavením písku na sítě o stejné velikosti oka byla získána také fauna mechovek, dekapodů, ryb a žraloků. Fosilní společenstvo bylo studováno pomocí binokulárních mikroskopů Olympus, Nikon a elektronového mikroskopu SEM Phenom Desktop (Bryozoa) na pracovištích jednotlivých autorů.

\section{Sedimentologie a petrografie}

Ve stěnách pískovny byly převážně zastiženy béžové jemně až středně zrnité silně slídnaté nepř́líš dobře vytříděné písky s laminami velmi hrubozrnného písku až štěrčíku (klasty do $1 \mathrm{~cm}$ v ose A). Charakteristické je šikmé zvrstvení velké škály, které se uklání generelně k JJZ až JZ. Typický 


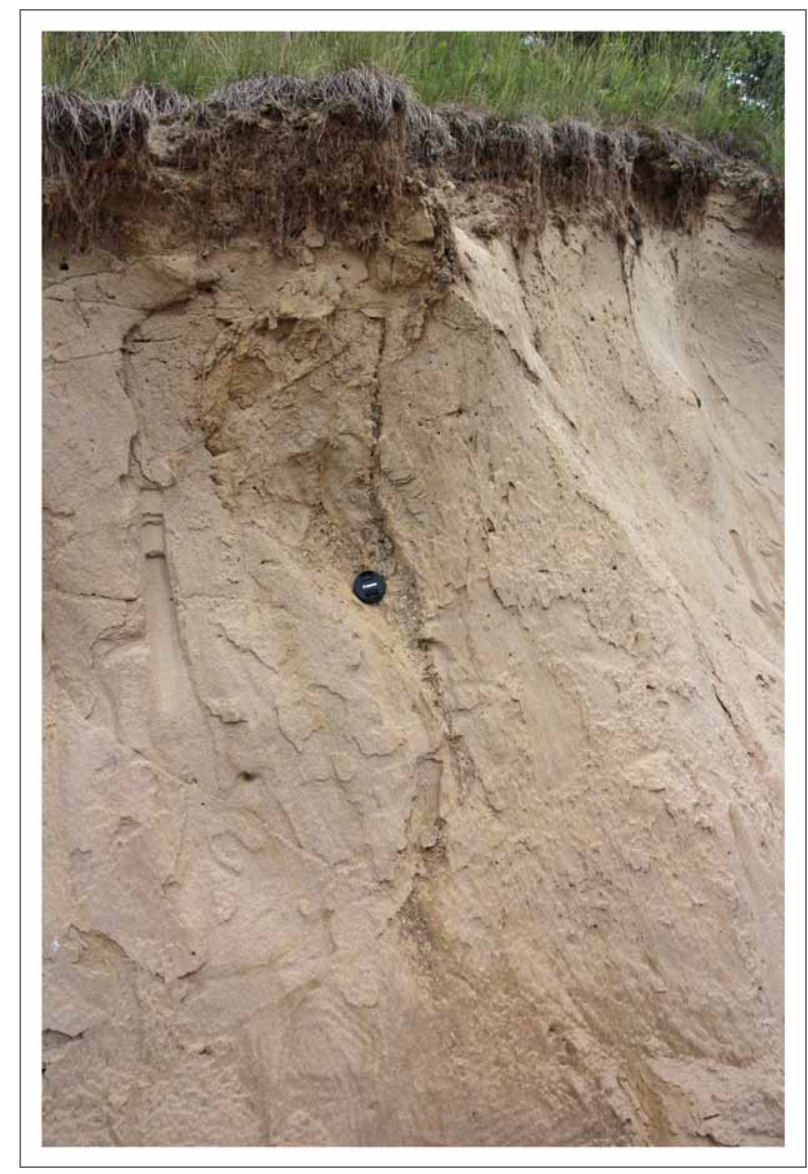

Obr. 3: Místo odběru vzorku C (jíl).

Fig. 3: Sampling point C (clay).

je značný sklon lamin (30-35). Mocnost jednotlivých písčitých cosetů je do $200 \mathrm{~cm}$ (sety jsou $20-50 \mathrm{~cm}$ mocné).

Psefitické klasty jsou z hlediska tvaru i zaoblení velmi nevytř́íděné (zjištěny byly poloostrohranné i zaoblené klasty). Podřízeně vystupují drobnozrnné štěrky $s$ podpůrnou stavbou písčité matrix až podpůrnou stavbou klastů, které vykazují špatně zřetelné planární zvrstvení („spaced inclined stratification“). Poloostrohranné až polozaoblené klasty mají velikost do $2 \mathrm{~cm}$ (osa A).

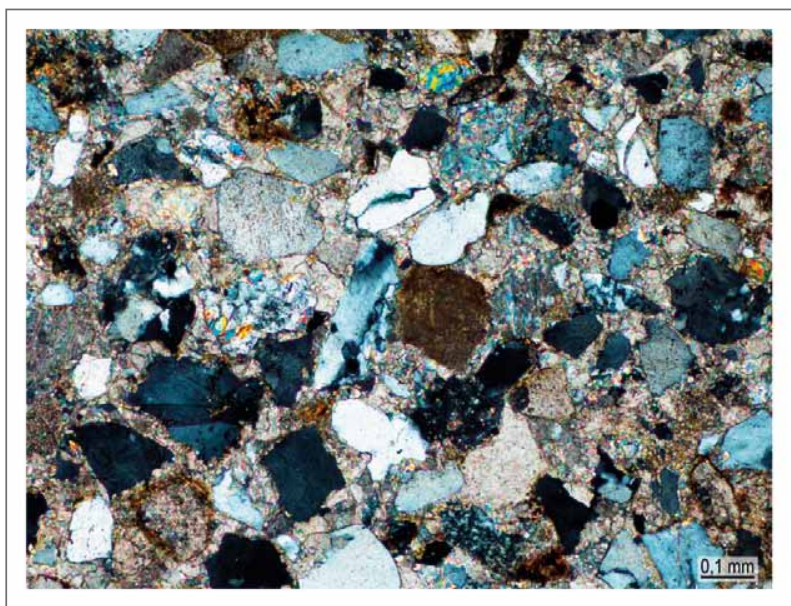

Obr. 4: Mikrofotografie jemno až střednozrnného vápnitého pískovce (XPL).

Fig. 4: Microphoto of fine to medium grained calcareous sandstone (XPL).
Nejdelší osa valounů je obvykle protažena rovnoběžně se zvrstvením, spíše podřízeně byla sledována orientace osy A kolmo ke zvrstvení. Štěrk je polymiktní, ve valounovém složení dominuje křemen. Charakteristická je přítomnost valounků tmavých rohovců a schránek ústřic či jejich drti. Mocnost těles štěrků je do $30 \mathrm{~cm}$. Báze i svrchní hranice písčitých a štěrkovitých těles jsou ukloněné, víceméně planární s jen drobným reliéfem.

Vzorek pískovce lze na základě výbrusového studia označit jako jemno- až střednozrnný vápnitý pískovec (obr. 4). Bazální pojivo je tvořeno karbonátem, který místy koroduje okolní zrna. Vytříděnost klastické složky je střední a opracovanost klastů je dobrá (dominují polozaoblenná až oválná zrna). V klastické složce dominuje polykrystalický i monokrystalický křemen (asi $20 \%$ ). Přibližně z $15 \%$ jsou zastoupeny živce (draselný i plagioklas), $\mathrm{z}$ nich některé podlehly sekundárním přeměnám. $\mathrm{Z}$ dalších komponentů jsou prrítomny okolo $3 \%$ lišty muskovitu, biotitu a ojediněle i chloritu. $Z$ horninových úlomků výrazně dominují klasty mikritových vápenců, dále byl zaznamenán kyselý vulkanit a kvarcit. Ojediněle byly pozorovány fragmenty neidentifikovatelných schránek organizmů. $\mathrm{Z}$ akcesorických minerálů byl rozeznán granát, zirkon, staurolit, glaukonit a epidot.

Písky jsou silně tektonicky postiženy puklinami a klastickými žílami, což je spojováno s pozicí před čelem př́krovů. Do písku na dvou místech zatékají tmavě hnědé střípkovitě rozpadavé jíly (neptunická žíla?). Z jílů byl odebrán vzorek C na mikropaleontologii (obr. 2 a 3).

Písky obsahují velké vápnito-pískovcové konkrece vejčitého a menhirovitého tvaru, v delší ose mají 2-4m (obr. 2).

Na povrchu terénu se v okolí pískovny vyskytuje ve značném množství polymiktní valounový materiál. Vrtnými pracemi Geologického průzkum n. p. Ostrava bylo zjištěno, že tyto valouny pocházejí z jílů, které pokrývají podložní písky a štěrky. Tyto jíly s valouny nevystupují $\mathrm{v}$ prostoru pískovny na povrch.

\section{Paleontologie \\ Dírkovci (foraminifera)}

Písek ze vzorku A (obr. 2) obsahoval bohaté společenstvo foraminifer, úlomky schránek měkkýšů, ostnů ježovek, fragmenty křemitých jehlic, zoária mechovek a kůstky, obratle a zoubek ryb (?). Ve společenstvu foraminifer jsou zastoupeny jak malé, tak i velké schránky, často poškozené, s ornamentací setřenou opracováním. Je tvořeno prakticky výhradně bentosem. Do karpatu je řazeno na základě výskytu úlomku druhu Uvigerina graciliformis Papp et Turn. Společenstvo foraminifer je relativně diverzifikované, nicméně hojněji se nacházejí jedinci rodu Lenticulina [L.cultrata (Mont.), L. macrodisca (Rss.), L. vortex (Ficht. et Moll), L. inornata (Orb.)] a Heterolepa dutemplei (Orb.). Dále se vyskytují druhy Elphidium crispum (L.), E. fichtelianum (Orb.), Pullenia bulloides (Orb.), Pyramidulina raphanistrum(L.), Amphicorynabadenensis (Orb.), Marginulina hirsuta Orb., Cassidulina laevigata Orb., Nonion commune (Orb.), Ammonia viennensis (Orb.), A. beccarii (L.), Bulimina schischkinskayae Sam. a další. 


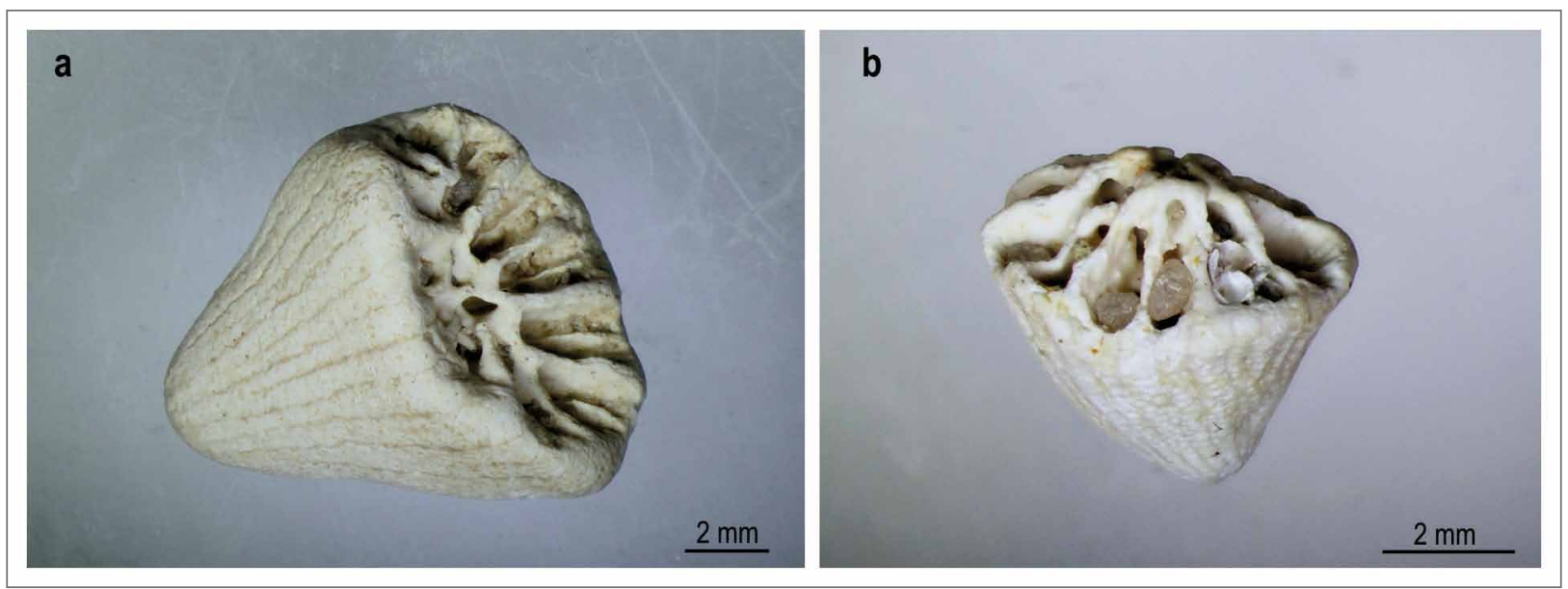

Obr. 5: Koráli: a - Flabellum sp.; b - Caryophyllidae gen. indet.

Fig. 5: Corals: a - Flabellum sp.; b - Caryophyllidae gen. indet.

Ve společenstvu se nalézají jak hlubokovodnější druhy, tak i druhy výrazně mělkovodní.

Z šedého vápnitého závalku (vzorek B, obr. 2) bylo vyseparováno společenstvo vesměs bentosních foraminifer doprovázené úlomky jehlic hub a ostnů ježovek. Oproti společenstvu z jemnozrnných písků je početně i druhově chudší. Drobné schránky jsou zastoupeny nejčastěji druhy Heterolepa dutemplei (Orb.), Nonion commune (Orb.) a euryoxybiontní Bolivina hebes MacFad. a Bulimina elongata Orb., dále se vyskytují např. Ammonia viennensis (Orb.), Hanzawaia boueana (Orb.), Pullenia bulloides (Orb.), Cassidulina laevigata Orb., Asterigerinata planorbis (Orb.), Neugeborina longiscata (Orb.) a Globigerina praebulloides Blow. Ve společenstvu se nevyskytovaly vůdčí fosilie pro karpat, nicméně jeho pozice, charakter i druhové složení na toto stáří ukazuje. Složením se liší od společenstva z jemnozrnného písku i jílové polohy, charakterem připomíná společenstva spíše mírně anoxického prostř̌edí.

Jíl vyplňující puklinu v písku (vzorek C, obr. 2 a 3) obsahoval poškozené, mnohdy opracované schránky výhradně bentosních foraminifer s hojnějším zastoupením lentikulin, úlomky schránek měkkýšů a kostí kostnatých ryb. Stáři karpatu dokládá úlomek druhu Uvigerina graciliformis Papp et Turn. Dále se nacházejí Lenticulina inornata (Orb.), L. cultrata (Mont.), L. macrodisca (Rss.), Heterolepa dutemplei (Orb.), Stilostomella sp., Bulimina elongata Orb., B. striata Orb., B. schischkinskayae Sam., Cassidulina laevigata Orb., Marginulina hirsuta Orb., Amphimorphina mucronata (Karr.) atd. Výše uvedené druhy svědčí o hlubším prostředí sedimentace než vzorky předcházející.

\section{Korálnatci (Anthozoa)}

Ve fosilním společenstvu se nacházelo 5 koralitů solitérního zástupce rodu Flabellum (obr. 5) a jeden zástupce čeledi Caryophyllidae. Schránky jsou silně zkorodované stejně jako ostatní studované fosilie. Hladil (1976) interpretuje korálovou faunu složenou z čeledí Caryophyllidae a Flabellidae jako indikátory infralitorálního prostředí, v němž jsou jejich zástupci velmi častí. Ojedinělost i zachování koralitů neumožňuje bližší vyjádření. Každopádně jejich přitomnost indikuje normální salinitu.

\section{Mechovky (Bryozoa)}

Ve společenstvu dominují druhy Cupuladria baluki Zágoršek a Reussirella haidingeri (Reuss) - viz obr. 6. Dále

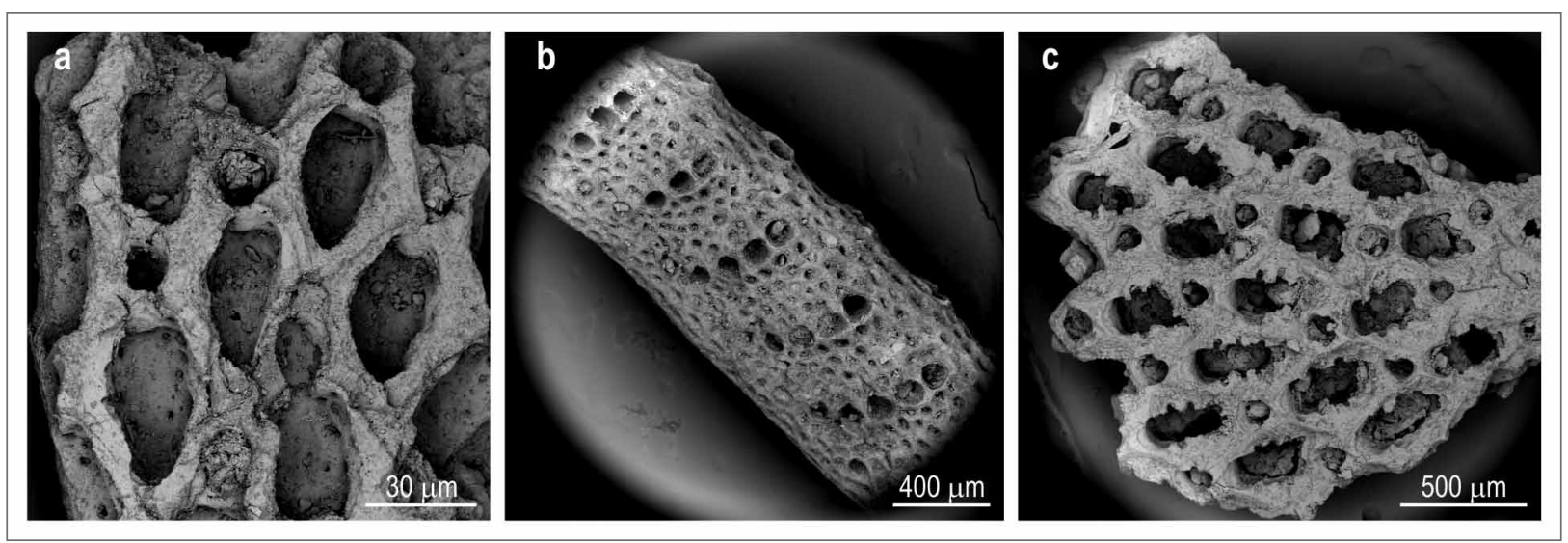

Obr. 6: Zoária mechovek (foceno v elektronovém miskroskopu): a - Cupuladria baluki Zág.; b - Polyascosoecia cancellata Canu; c-Reussirella haidingeri (Rss.).

Fig. 6: Zoaria of bryozoans (photographed in an electron microscope): a - Cupuladria baluki Zág.; b - Polyascosoecia cancellata Canu; c - Reussirella haidingeri (Rss.). 
jsou zastoupeny druhy Polyascosoecia cancellata Canu, Hornera sp. a Cellaria ? fistulosa (Linn.). Dominantní druhy mechovek ukazují na „hardground“. Patří k volně žijícím druhům, které potřebují tvrdé dno, po kterém by se mohly pohybovat. Indikují prostředí s relativně vysokou dynamikou. Ostatní druhy jsou výrazně oportunistické a žijí téměř všude. Celkově mechovky indikují hloubky do $100 \mathrm{~m}$.

\section{Měkkýši (Mollusca)}

Studovaná asociace měkkýšů je relativně početná (105 ks), výrazně převažují plži nad mlži a kelnatkami (viz elektronická příloha). Povrch schránek je vesměs více či méně navětralý, většina schránek je poškozená, resp. fragmentární, některé nesou stopy ohlazení či oválení. Mezi gastropody jednoznačně dominuje druh Granulolabium plicatum (Brug.), početněji byly dále zastoupeny druhy Nassarius edlaueri (Beer-Bistr.), Turritella eryna

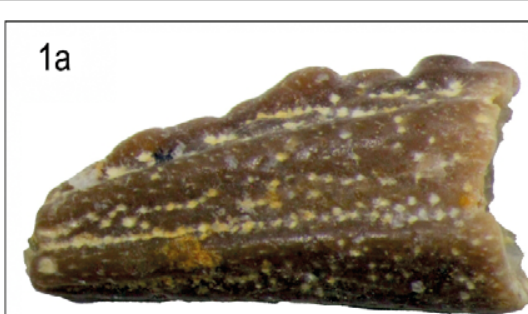

$1 \mathrm{~b}$

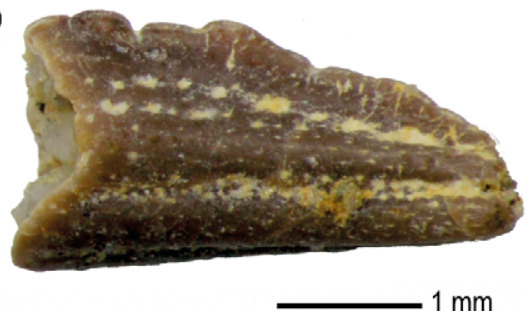

2

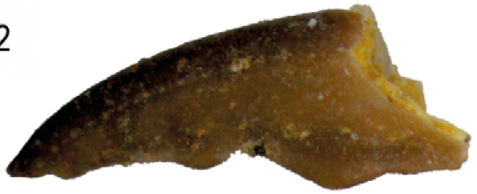

3

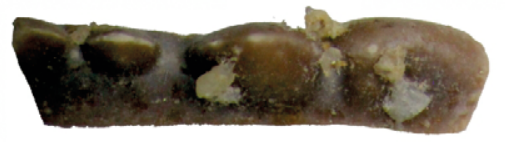

4

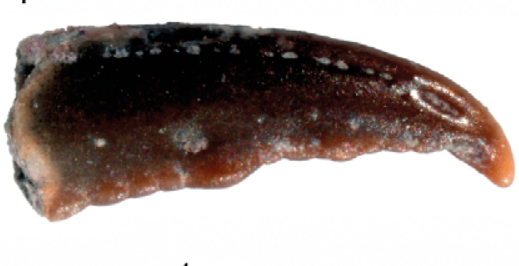

5

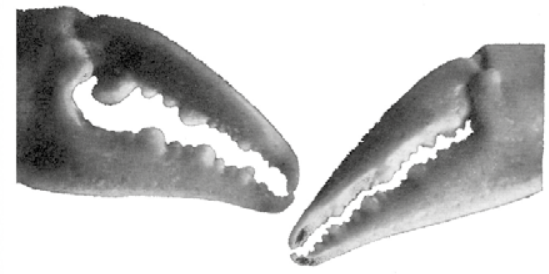

$1 \mathrm{~mm}$

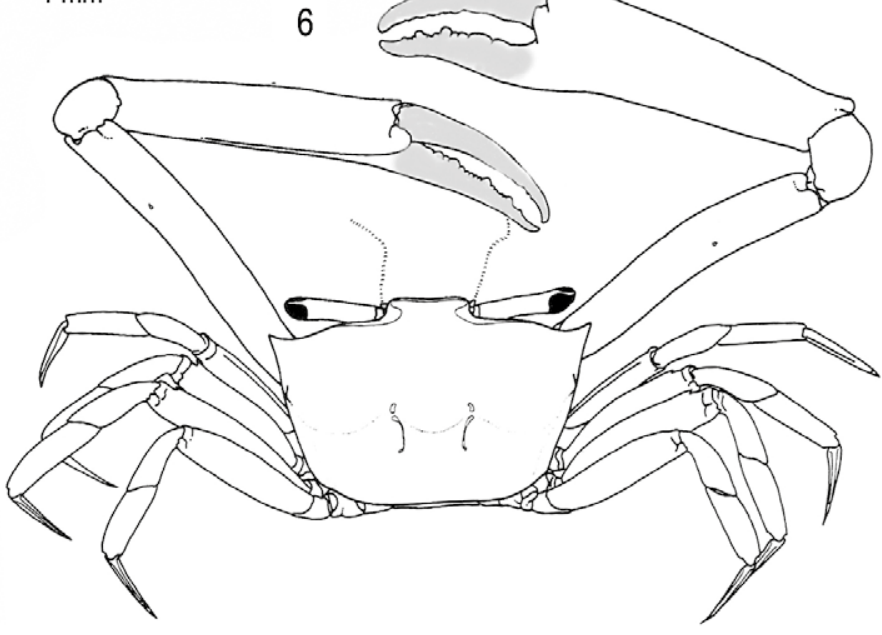

Obr. 7: Fragmenty decapodů: 1- Goneplax sp., pevný prst klepeta, Litenčice; 2 - Goneplax sp., cheliped dactylus, Litenčice; 3 - Goneplax sp., pohyblivý prst klepeta (?), okluzální pohled, Litenčice; 4 - Goneplax gulderi Bachm., pohyblivý prst klepeta; Badenian, Baden-Sooss; 5 - Goneplax rhomboides (L.), prsty klepet; recent (Bachmayer 1953); 6 - Goneplax rhomboides (Linnaeus, 1758), habitus; recent (González Guirriarán, Méndez 1985). Prsty klepet jsou zvýrazněny šedou barvou.

Fig. 7: Fragments of decapods: 1- Goneplax sp., cheliped fixed finger, Litenčice; 2 - Goneplax sp., cheliped dactylus, Litenčice; 3 - Goneplax sp., cheliped dactylus (?) in occlusal view, Litenčice; 4 - Goneplax gulderi Bachm., cheliped dactylus; Badenian, Baden-Sooss; 5 - Goneplax rhomboides (L.), cheliped fingers; modern (from Bachmayer 1953); 6 - Goneplax rhomboides (Linnaeus, 1758), habitus; modern (from González Guirriarán, Méndez 1985). Cheliped fingers are highlighted with gray colour.
Orb. a Turris cf. trifasciata (Hoern.). Ostatní druhy se vesměs vyskytovaly pouze v 1-2 exemplářích. Z mlžů jsou relativně nejhojnější fragmenty různých druhů ústřic a Venus sp., resp. Veneroidea indet. Kelnatky se ve studovaných vzorcích vyskytly pouze ojediněle.

Nalezené druhy indikují obecně mořské prostředí. Relativně početné jsou brakické, resp. euryhalinní elementy Granulolabium plicatum (Brug.), G. bicinctum (Brocchi), Nassarius sp., Terebralia bidentata (Def. in Grateloup), Agapilia pachii (Hoern.). Oba druhy rodu Granulolabium jsou extrémně euryhalinní a představují dobré faciální indikátory pro litorální biotopy. Rovněž druh Agapilia pachii (Hoern.) naznačuje vliv brakické vody (Harzhauser 2002a). V asociaci se však současně vyskytují i prvky stenohalinní (turritelly, rody Arca, Clavatula, Xenophora, Conus, kelnatky aj.), které nasvědčují tomu, že salinita vody byla proměnlivá nebo, že jde o oryktocenózu měkkýšů splavených $\mathrm{z}$ různých biotopů.

Zjištěné taxony měkkýšů Anadara diluvii (Lam.), Ostrea digitalina (Dubois), Clavatula sp., Turritella div. sp., Conus sp. aj. vesměs preferují mělkovodní prostředí (sublitorál, resp. infralitorál), s vyšší dynamikou. Výskyt zástupců vagilního i sesilního bentosu, a to jak infauny (rody Venus, Nassarius aj.), tak i epifauny (Ostrea sp., 
Xenophora sp., kelnatky aj.) svědčí o tom, že substrát jako celek byl hojně osídlen a prostředí dostatečně prokysličeno [v asociaci se objevují ojediněle i rody/druhy tolerantní ke snížení obsahu kyslíku - např. Nassarius, Hinia, Euspira helicina (Brocchi)]. Z hlediska způsobu získávání potravy se mezi měkkýši vyskytují filtrátoři (rody Anadara, Venus aj.), detritofágové (např. turritelly aj.) a poměrně hojní jsou predátoři či požírači mršin: taxony Conus, Hexaplex, Nassarius, Hinia, Euspira, Muricidae (Bagdasaryan et al. 1966; Tatishvili et al. 1968; Dulai 1996; Harzhauser 2002a, b). Stopy predace - provrty - byly přímo pozorovány i na některých schránkách. Většina zjištěných druhů preferuje měkký substrát - jílovitý, písčitý či písčitojílovitý. Přítomnost epibiontů, resp. sesilního bentosu (Ostrea sp. aj.), nicméně naznačuje i (lokální?) př́tomnost substrátu pevného. Nalezená asociace měkkýšů zahrnuje převážně druhy preferující teplé vody (Bagdasaryan et al. 1966; Tatishvili et al. 1968; Dulai 1996; Harzhauser 2002a, b).

Asociace mlžů a kelnatek z lokality Litenčice není z biostratigrafického hlediska průkazná, nebot zahrnuje (i vzhledem k nemožnosti přesnější determinace některých fragmentů) vesměs průběžné miocenní druhy s výskytem (minimálně) od eggenburgu po baden, $v$ zásadě však není v rozporu s nálezy uváděnými z jiných lokalit karpatského stáří (mlži - Čtyroký 2002; Mandic 2003; kelnatky - Harzhauser 2002b, 2003). Fauna gastropodů má biostratigrafický potenciál poněkud větší. Nepochybně nejvýznamnější je přítomnost druhu Agapilia pachii (Hoern.), který je uváděn výhradně $\mathrm{z}$ karpatu (Harzhauser 2002a, 2003). Druhy Hexaplex cf. pomiformis (Eich.),

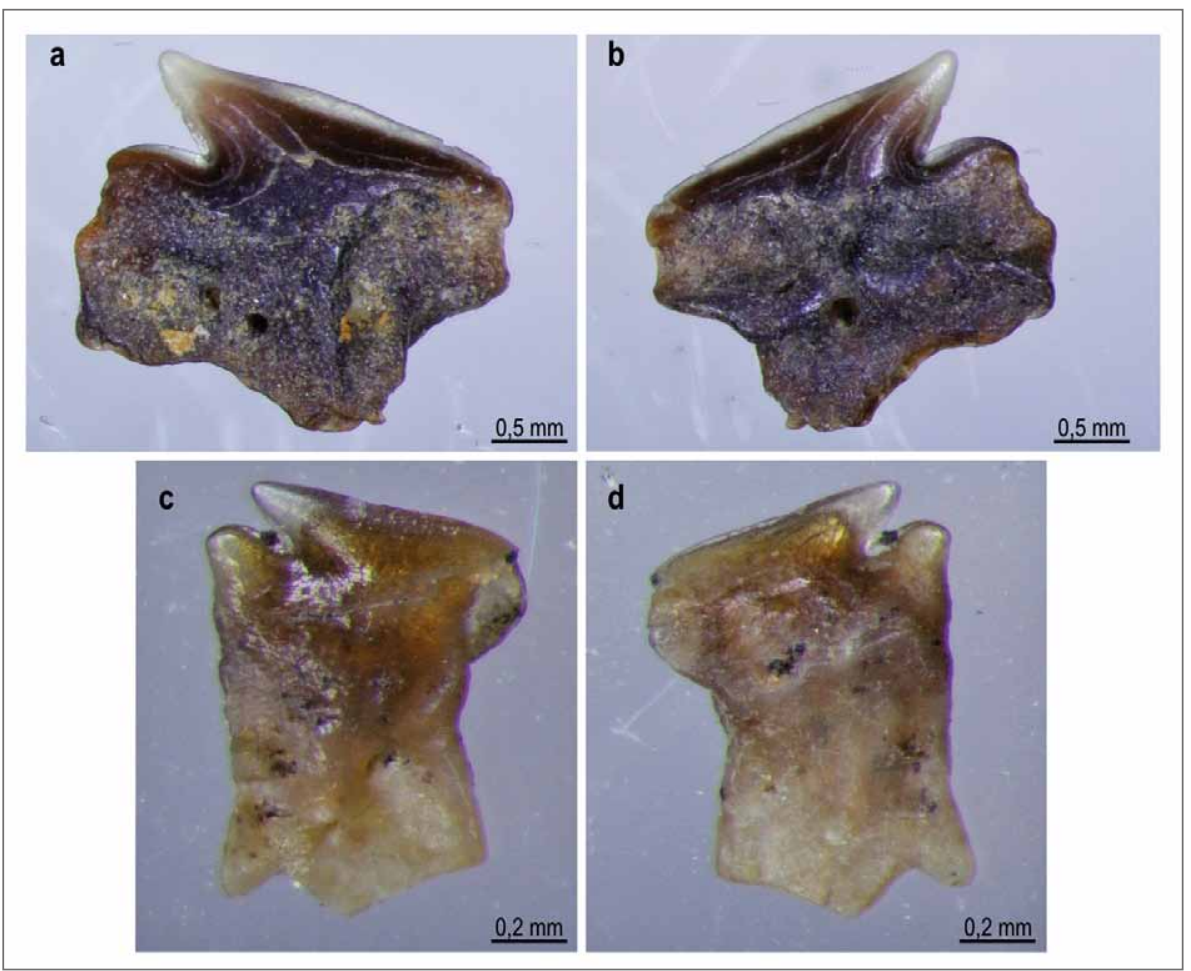

Obr. 8: Žraločí zuby: Centrophorus sp. (a - labiální pohled, b - linguální pohled); Paraetmopterus sp. (c - labiální pohled, d - linguální pohled).

Fig. 8: Shark teeth: Centrophorus sp. (a - labial view, b - lingual view); Paraetmopterus sp. (c - labial view, d - lingual view).
Ocenebra striata (Eich.) či Clavatula cf. laevigata (Eich.) se vyskytují v Centrální Paratethydě od karpatu, druhy Turritella bicarinata (Eich.) či Nassarius edlaueri (Beer-Bistr.) zaznamenávají v karpatu rozkvět, druh Terebralia bidentata (Def. in Grateloup) acme (Harzhauser 2002a, 2003). Většina gastropodů zjištěných v Litenčicích je známa rovněž z různých lokalit karpatského stáří Centrální Paratethydy (jejich souhrn viz Harzhauser 2003).

\section{Desetinožci (Decapoda)}

K dispozici bylo několik fragmentů klepítek: pevný prst (obr. 7-1a, b) i fragmenty pohyblivých prstů (obr. 7-2 a 7-3). Zachování neumožňuje určení na druhové úrovni, ale morfologie jednoho pohyblivého prstu (obr. 7-2) odpovídá druhu Goneplax gulderi Bach. (obr. 7-4), popsaného ze spodního a středního miocénu centrální Evropy (Bachmayer 1953; Garassino et al. 2013). Pevný prst, i když fragmentární, se podobá pevnému prstu (obr. 7-1a, b) dnešního zástupce rodu Goneplax. Zástupci rodu Goneplax jsou charakterizováni podlouhlými očními stopkami, interpretovanými jako adaptace na zahrabávání do substrátu a vyhýbání se predátorům na povrchu sedimentu (Barnes 1968). Dnes žijící druh Goneplax rhomboides (Lin.) (obr. 7-5 a 7-6) je obyvatelem subtidálního měkkého dna (Castro 2007). Müller (1984) představil výsledky shlukové analýzy, ve které studoval environmentální preference příslušných střednomiocénních (badenských) krabů. Goneplax v jeho interpretaci upřednostňoval měkké substráty (jemný písek až bahno) také v geologické minulosti. Původní popis druhu Goneplax gulderi od Bachmayera (1953) vychází z materiálu získaného $\mathrm{z}$ „Badener Tegel“ cihelny $\mathrm{v}$ Baden-Sooss v Rakousku (Rögl et al. 2008), a také další výskyty jsou známy z lokalit s podobnými sedimentárními podmínkami (Hyžný, nepublikovaná data).

\section{Chondrichthyes (Selachii a Rajiformes)}

Plavením vzorku D (obr. 2) bylo získáno a determinováno celkem 9 kusů žraločích zubů a 2 kusy zubů rejnoka. Vesměs se jedná o korodované exempláře a nelze je druhově zařadit. Byli identifikováni 3 zástupci squaliformních žraloků: Deania (1 ks), Paraetmopterus (1 ks), Centrophorus (1 ks, obr. 8), zub kladivouna Sphyrna (1 ks) a dále blíže neurčení zástupci máček z čeledi Scyliorhinidae (4 ks). Z rejnoků se ve společenstvu nacházejí zoubky trnuchy rodu ?Dasyatis. 
Všechny zuby jsou převážně milimetrových velikostí. Jediný větší, ale nekompletní zub, patří pravděpodobně rodu Carcharias.

Rody Deania a Paraetmopterus byly nedávno popsány $\mathrm{z}$ badenských sedimentů $\mathrm{v}$ Brně-Divišově čtvrti (Tomanová et al. 2018). Zástupci rodů Sphyrna, Carcharias,? Dasyatis a čeledi Scyliorhinidae jsou např. známy z badenské lokality Kinberk (Schultz et al. 2010), rod Carcharias i z oligocénu šitbořických vrstev (Cappetta et al. 2016). Rod Centrophorus je v karpatské předhlubni zaznamenán vůbec poprvé.

\section{Kostnaté ryby (Teleostei)}

$\mathrm{Z}$ výplavu vzorku D byly získány hojné fragmenty obratlů, ploutevních paprsků, kostí lebky, dále 8 izolovaných zubů kostnatých ryb a několik otolitů.

Zuby patří převážně zástupcům čeledi Trichiruidae (5 ks). Dále zde byly identifikovány zuby sparidních ryb rodů Diplodus (2 ks) a Crenidens (1 ks).

Otolity kostnatých ryb jsou vesměs silně oválené, úlomkovité a patří většinou juvenilním exemplářům. Převažují jedinci druhu Lampanyctus carpaticus (Brz.), méně časté a úlomkovité jsou blíže neurčitelné otolity Diaphus sp. Oba taxony představují zástupce ryb se světelnými orgány čeledi Myctophidae charakteristické pro mezopelagické prostředí. Migrační rytmus těchto ryb je však typický nočním vertikálním pohybem ve sloupci vody do epipelagiálu velmi blízko $\mathrm{k}$ hladině. Pro epipelagiál s možnými vertikálními migracemi a tolerancí $\mathrm{k}$ anoxii svědčí i zcela ojedinělý juvenilní otolit rodu Bregmaceros. Zachování i taxonomická chudost otolitů však otevírá i úvahu o případné redepozici otolitů $\mathrm{z}$ vápnitých jílů a jílovců do mělkovodního prostředí holešovských vrstev kroměřížského souvrství před čely prríkrovů. Zvláště L. carpaticus je v pelitech kroměřížského souvrství pod a před příkrovy velmi hojný. V tomto smyslu je použití otolitů pro hodnocení sedimentačního prostředí holešovských vrstev problematické.

\section{Paleoekologie}

Společenstvo foraminifer je tvořeno prakticky výhradně bentosem. Je relativně diverzifikované, hojněji se nacházejí jedinci rodu Lenticulina. Ve společenstvu se nalézají jak hlubokovodnější druhy, tak i druhy výrazně mělkovodní. Všechna indikují mořské prostředí sedimentace.

Mechovky patří k volně žijícím druhům, které potřebují tvrdé dno, po kterém by se mohly pohybovat. Indikují prostředí s relativně vysokou dynamikou a hloubky do $100 \mathrm{~m}$.

Měkkýší fauna dokládá obecně mořské prostředí. Relativně početné jsou brakické, resp. euryhalinní elementy. V asociaci se však současně vyskytují i prvky stenohalinní, které nasvědčují tomu, že salinita vody mohla být krátkodobě proměnlivá. Zjištěné druhy měkkýšů vesměs preferují mělkovodní prostředí (sublitorál, resp. infralitorál s vyšší dynamikou). Výskyt zástupců vagilního i sesilního bentosu svědčí o tom, že substrát jako celek byl hojně osídlen a prostředí dostatečně prokysličeno (v asociaci se objevují ojediněle i rody/druhy tolerantní ke snížení obsahu kyslíku). Tomuto prostředí odpovídá i přítomnost kraba rodu Goneplax, který indikuje prostředí subtidálního měkkého dna v hloubkách od 3 do $750 \mathrm{~m}$ (Neumann et al. 2010).

Korálová fauna indikuje infralitorální prostředí.

Společenstvo žraloků a kostnatých ryb patří převážně k hlubokovodním skupinám. Recentní druh Deania calcea (Lowe) obývá zóny v blízkosti dna v hloubkách od 60 do 1490 m, obvykle žije v hloubkách 400-1 490 m (Cox, Francis 1997) a Springer (1990). Recentní zástupce čeledi Etmopteridae Etmopterus spinax (Linn.) je batydemerzální, pohybující se v hloubkách 200-2 490 m, obvykle v hloubce 200-500 m (Jones et al. 2003). Recentní zástupce čeledi Centrophoridae Centrophorus granulosus (Bloch et Schneider) je batydemersální s hloubkovým rozsahem 50-1 440 m, obvykle 200-600 m (Compagno 1984). Na druhé straně kladivoun Sphyrna zygaena (Linn.) žije v menších hloubkách od 0 do $200 \mathrm{~m}$ (Compagno et al. 1989) stejně jako demersální Dasyatis pastinaca (Linn.), která však preferuje hloubky většinou mezi 20-35 m (Brito 1991; Reiner 1996).

Zástupci čeledi Trichiuridae žijí převážně bentopelagicky v hloubkách pod 200 m (Nakamura a Parin 1993). Zástupci čeledi Myctophidae patř́i mezi mezopelagické druhy pohybující se ve velkém hloubkovém rozmezí mezi 300-1 $200 \mathrm{~m}$ během dne a $10-100 \mathrm{~m}$ během noci (Paxton et al. 1984). Pouze zástupci čeledi Sparidae patř́i vysloveně k mělkovodním druhům. Např. recentní druh Diplodus puntazzo (Walb.) se pohybuje v hloubkách od 0 do $120 \mathrm{~m}$ (Schneider 1990) a Crenidens crenidens (Forss.) žije v mělkém př́ibřežním prostředí na bahnitém podkladu (Smith, Smith 1986).

\section{Diskuze a závěr}

Studované písky a štěrky holešovských vrstev kroměřížského souvrství jsou interpretovány jako sedimenty gravitačních proudů, přesněji hustých turbiditních proudů (high-density turbidity currents) ve smyslu Lowe (1982). Depoziční prostředí lze nejspíše umístit na podmořské svahy hrubozrnné delty Gilbertovského typu (tzv. foresety). Tento typ sedimentace ukazuje na výraznou morfologii depozičního prostoru i zdrojové oblasti, intenzivní prrínos materiálu a dynamické podmínky transportu a depozice. Obdobné sedimenty jsou často spojovány s významnou přestavbou depoziční pánve při hranici karpat/baden.

Detritické granáty, jako akcesorické minerály, hojně zastoupené v píscích a pískovcích, studovali na lokalitě Litenčice Francírek a Nehyba (2017). Z jejich statistického zpracování vyplývá, že sedimenty holešovských vrstev byly dotovány materiálem ždánicko-podslezské jednotky (ždánicko-hustopečské souvrství) a prrípadně starší sedimentární výplně karpatské předhlubně.

Paleontologický obsah uloženin dobře koresponduje se sedimentologickou interpretací. Společenstva různých skupin (foraminifery, mechovky, měkkýši, koráli, desetinožci, žraloci a kostnaté ryby) vykazují jak úlomkovitým či korodovaným zachováním fosílií, promícháním taxonů 
$\mathrm{z}$ různých prostředí $\mathrm{z}$ hlediska salinity i paleobatymetrie na to, že většina fosilních zbytků nebyla uložena in situ a prodělala před uložením větší či menší transport. Není vyloučena ani redepozice $\mathrm{z}$ o něco starších miocenních sedimentů. Především mechovky, měkkýši a koráli podporují výklad prostředí s relativně vysokou dynamikou a hloubky vody do $100 \mathrm{~m}$. Sedimenty $z$ Litenčic je možné zařadit do karpatu na základě výskytu úlomku druhu Uvigerina graciliformis Papp et Turn., otolitů myctophidního druhu Lampanyctus carpaticus Brz. a gastropoda druhu Agapilia pachii (Hoern.).

\section{Poděkování}

Článek vznikl na základě institucionální podpory dlouhodobého koncepčního rozvoje výzkumné organizace poskytované Ministerstvem kultury (DKRVO, MK000094862), dále v rámci interních projektů ČGS č. 343100 a 310340, které jsou součástí DKRVO/ČGS (2018-2022) a v rámci projektu CZ.1.07/2.3.00/20.0166 (CETPO).

Autoři děkují Henrimu Cappettovi a Sylvainovi Adnetovi za konzultaci při determinaci žraločích zubi̊. Rovněž vděči editorovi D. Buriánkovi a recenzentưm N. Dolákové a M. Bubíkovi za podnětné pripomínky.

\section{Literatura}

Bachmayer, F. (1953). Goneplax gulderi, eine neue Crustaceen-Species aus dem tortonischen Tegel des Wiener-Beckens. - Paläontologische Zeitschrift, 27, 143-145. https://doi.org/10.1007/BF03041844

Bagdasaryan, K. G., Tatishvili, K. G., Kazachashvili, Z. R., Muschelishvili L. V. et al. (1966). Spravochnik po ekologii morskich dvustvorok. - Nauka, 71-79. Moskva.

Barnes, R. S. K. (1968). On the evolution of elongate ocular peduncles by the Brachyura. - Systematic Zoology, 17, 182-187. https:// doi.org/10.2307/2412361

Brito, A. (1991). Catalogo de los pesces de las Islas Canarias. - Francisco Lemus, la Laguna.

Cappetta, H., Gregorová, R., Adnet, S. (2016). New selachian assemblages from the Oligocene of Moravia (Czech Republic). Neues Jahrbuch für Geologie und Paläontologie - Abhandlungen 280, 3, 259-284.

Castro, P. (2007). A reappraisal of the family Goneplacidae MacLeay, 1838 (Crustacea, Decapoda, Brachyura) and revision of the subfamily Goneplacinae, with the description of 10 new genera and 18 new species. - Zoosystema, 29, 609-774.

Compagno, L. J. V. (1984). FAO Species Catalogue. Vol. 4. Sharks of the world. An annotated and illustrated catalogue of shark species known to date. Part 1 - Hexanchiformes to Lamniformes. - FAO Fish. Synop. 125 (4/1), 1-249. Rome, FAO.

Compagno, L. J. V., Ebert, D. A, Smale, M. J. (1989). Guide to the sharks and rays of southern Africa. - New Holland (Publ.) Ltd., London. $158 \mathrm{pp}$.

Cox, G., Francis, M. (1997). Sharks and rays of New Zealand. - Canterbury University Press, University of Canterbury. 68 pp.

Čtyroký P. (2002). Marine und brachyhaline Bivalven auds dem Karpatium des Korneuburger Beckens (Untermiozän; Österreich). - In: Sovis W., Schmid B., (eds): Das Karpat des Korneubuger Beckens, Teil 2, 215-258. Wien. 
Databáze významných geologických lokalit [databáze online]. Praha, Čes. geol. služba., 1998 [citováno 2020-02-05]. Dostupné z URL http:// lokality.geology.cz.

Dulai, A. (1996). Taxonomic composition and palaeoecological features of the Early Badenian (Middle Miocene) bivalve fauna of Szob (Börzsöny Mts, Hungary). - Annales historico-natutrales Musei Nationalis Hungarici, 88, 31-56.

Francírek, M., Nehyba, S. (2017). Nové poznatky k provenienci sedimentů kroměřížského souvrství. - Zprávy o geologických výzkumech, 50, 45-49.

Garassino, A., Pasini, G., Castro, P. (2013). Revision of the fossil species of Goneplax Leach, 1814 (Crustacea, Decapoda, Brachyura, Goneplacidae). - Boletín de la Sociedad Geológica Mexicana, 65, 355-368.

Harzhauser, M. (2002a). Marine und brachyhaline Gastropoden aus dem Karpatium des Korneuburger Beckens und der Kreuzstettener Bucht (Österreich, Untermiozän). - In: Sovis, W., Schmid, B. (eds): Das Karpat des Korneubuger Beckens, Teil 2, 61-160. Wien.

Harzhauser, M. (2002b). Scaphopoda aus dem Karpatium (Untermiozän) des Korneuburger Beckens (Niederösterreich). - In: Sovis, W., Schmid, B., eds. Das Karpat des Korneubuger Beckens, Teil 2, 205-214. Wien.

Harzhauser, M. (2003). Marine Gastropods, Scaphopods and Cephalopods of the Karpatian in the Central Paratethys. - In: Brzobohatý, R., Cicha, I., Kováč, M., Rögl, F. (eds): The Karpatian. A Lower Miocene Stage of the Central Paratethys. Masaryk University, 193-202. Brno.

Hladil, J. (1976). Šestičetni korali (Scleractinia) badenu karpatske předhlubně na Moravě. - MS, diplomová práce. Přírodovědecká fakulta Masarykovy univerzity. Brno.

Jones, E. G., Tselepides, A., Bagley, P. M., Collins, M. A., Priede, I. G. (2003). Bathymetric distribution of some benthic and benthopelagic species attracted to baited cameras and traps in the deep eastern Mediterranean. - Marine ekology progress series, 251, 75-86. https://doi.org/10.3354/meps251075

Košinarová, H., Pacák, F., Vinčar, F., Vocílka, M., Volný, R. (1986). Souhrnná závěrečná zpráva Brankovice - Uherský Brod. Surovina - materiál pro násypy a cementové stabilizace. Etapa vyhledávací průzkum. Stav zásob ke dni 13. 5. 1986., Dílčí zpráva o vyhledávacím geologickém průzkumu na lokalitě Litenčice, 1-7. - MS Geologický průzkum Ostrava, závod Modřice.

Lowe, D. R. (1982). Sediment gravity flows: II. Depositional models with special reference to the deposits of high-density turbidity currents. - Jouranl of Sedimentology and Petrol, 52, 279-297.

Mandic, O. (2003). Bivalves of the Karpatian in the Central Paratethys. - In: Brzobohatý, R., Cicha, I., Kováč, M., Rögl, F. (eds): The Karpatian. A Lower Miocene Stage of the Central Paratethys. - Masaryk University, 217-228. Brno.

Melion, V. J. (1853). Bericht über das Vorkommen fossiler, tertiärer Mollusken bei Littentschitz, Lomniczka und Rossitz. - Jahrbuch der Kaiserlich-Königlichen Geologischen Reichsanstalt. IV. Jahrgang. Reichsanstalt 1853, 703, Wien.

Müller, P. (1984). Decapod Crustacea of the Badenian. - Geologica Hungarica, Series Palaeontologica, 42, 3-317.

Nakamura, I., Parin, N. V. (1993). Snake mackerels and cutlassfishes of the world (families Gempylidae and Trichiuridae). - An annotated and illustrated catalogue of the snake mackerels, snoeks, escolars, gemfishes, sackfishes, domine, oilfish, cutlassfishes, scabbardfishes, hairtails, and frostfishes known to date. - FAO species catalogue. Vol. 15, FAO Fish. Synop., $125,15,136 \mathrm{p}$.

Nemec, W. (2005). Principles of lithostratigraphic logging and facies analyses. - Institutt for geovitenskap, 1-28. Bergen.

Neumann, H., Kröncke, I., Ehrich, S. (2010). Establishment of the angular crab Goneplax rhomboides (Linnaeus, 1758) (Crustacea, Decapoda, Brachyura) in the southern North Sea. -Aquatic Invasions 5(1): 27-30.

Paxton, J. R., Moser, H. G, Ahlstrom, E. H. (1984). Myctophidae: Relationships. - In: Moser, H. G., Richards, W. J., Cohen, D. M., Fahay, M. P., Kendall A. W., Jr., Richardson, S. L. (eds): Ontogeny and systematics of fishes, American Society of Ichthyologists and Herpetologists, 239-244, Special publications, Lawrence, Kansas.

Posamentier, H. W., Walker, R. G. (2006). Facies Models-revisited. - SEPM Spec. Publ., 1-521.

Reiner, F. (1996). Catálogo dos peixes do arquipélago de Cabo Verde. - Publicacoes avulsas Instituto Portugues de Investigacao Maritima, 2, $339 \mathrm{pp}$.

Rögl, F., Ćorić, S., Harzhauser, M., Jimenez-Moreno, G., Kroh, A., Schultz, O., Wessely, G. Zorn, I. (2008). The Middle Miocene Badenian stratotype at Baden-Sooss. - Geologica Carpathica, 59, 367-374.

Schneider, W. (1990). FAO species identification sheets for fishery purposes. Field guide to the commercial marine resources of the Gulf of Guinea. Prepared and published with the support of the FAO Regional Office for Africa. - Rome: FAO. 268 pp.

Schultz, O., Brzobohatý, R., Kroupa, O. (2010). Fish teeth from the Middle Miocene of Kienberg at Mikulov, Czech Republic, Vienna Basin. - Annalen des Naturhistorischen Museums in Wien, Wien, 112, A, 489-506.

Smith, J. L. B., Smith, M. M. (1986). Sparidae. - In: Smith, M. M., Heemstra, P. C. (eds): Smiths`sea fishes. - Springer-Verlag, 580-594. Berlin.

Springer, S., (1990). Squalidae. - In: Quero, J. C., Hureau, J. C., Karrer, C., Post, A., Saldanha, L. (eds): Check-list of the fi shes of the eastern tropical Atlantic (CLOFETA). - JNICT, Lisbon; SEI, Paris; and UNESCO, Paris. Vol. 1., 7-19.

Tatishvili, K. G., Bagdasaryan, K. G., Kazachashvili, Z. R. (1968). Spravochnik po ekologii morskich bryuchonogich. - Nauka, 54-55. Moskva.

Tomanová Petrová, P., Nehyba, S., Diviš, K., Hladilová Š., Gregorová R., Vít, J., Hudec, P. (2018). Paleoprostředí ve spodním badenu na severním okraji Brna (Divišova čtvrt). - Geologické výzkumy na Moravě a ve Slezsku, 25, 1-2, 65-72. https:// doi.org/10.5817/GVMS2018-1-2-65

Tucker, M. (1988). Techniques in Sedimentology, Blackwell Science, 1-394.

Walker, R. G. (ed.) (1984). Facies Models, Second Edition. - Geological Association of Canada, 317 pp.

Walker, R. G., James, N. P. (1992). Facies Models. Response to sea level changes. - Geological Association of Canada, 1-380; Toronto. https://doi.org/10.1002/gj.3350290317 